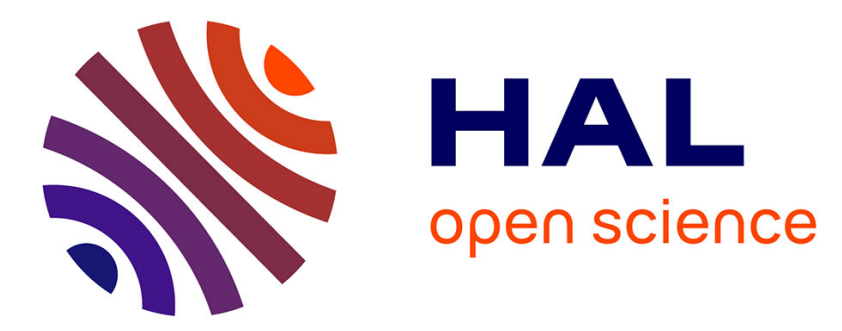

\title{
Establishment of cellulolytic bacteria and development of fermentative activities in the rumen of gnotobiotically-reared lambs receiving the microbial additive Saccharomyces cerevisiae CNCM I-1077
}

Frédérique Chaucheyras-Durand, Gérard Fonty

\section{To cite this version:}

Frédérique Chaucheyras-Durand, Gérard Fonty. Establishment of cellulolytic bacteria and development of fermentative activities in the rumen of gnotobiotically-reared lambs receiving the microbial additive Saccharomyces cerevisiae CNCM I-1077. Reproduction Nutrition Development, 2001, 41 (1), pp.57-68. 10.1051/rnd:2001112 . hal-00900420

\author{
HAL Id: hal-00900420 \\ https://hal.science/hal-00900420
}

Submitted on 1 Jan 2001

HAL is a multi-disciplinary open access archive for the deposit and dissemination of scientific research documents, whether they are published or not. The documents may come from teaching and research institutions in France or abroad, or from public or private research centers.
L'archive ouverte pluridisciplinaire HAL, est destinée au dépôt et à la diffusion de documents scientifiques de niveau recherche, publiés ou non, émanant des établissements d'enseignement et de recherche français ou étrangers, des laboratoires publics ou privés. 


\title{
Establishment of cellulolytic bacteria and development of fermentative activities in the rumen of gnotobiotically-reared lambs receiving the microbial additive Saccharomyces cerevisiae CNCM I-1077
}

\author{
Frédérique CHAUCHEYRAS-DURAND ${ }^{\mathrm{a}, \mathrm{b}} *$, Gérard FONTY $^{\mathrm{a}}$ \\ a Laboratoire de Microbiologie, INRA, Centre de Recherches de Clermont-Ferrand Theix, \\ 63122 Saint-Genès-Champanelle, France \\ b LALLEMAND, 15130 Saint-Simon, France
}

(Received 23 October 2000; accepted 22 January 2001)

\begin{abstract}
We studied the effects of a yeast additive used in ruminant nutrition on the establishment of cellulolytic bacteria, on plant cell wall degradation and on digestive functions in the rumen of gnotobiotically-reared lambs. Cellulolytic bacteria inoculated to the lambs tended to become established earlier in the presence of Saccharomyces cerevisiae CNCM I-1077 (SC). In addition, their population was maintained at a higher level, when the physico-chemical conditions of the biotope were altered. In these lambs, specific activities of fibrolytic enzymes were greater, and in sacco degradation of wheat straw tended to increase. In the presence of SC there was a decrease in ruminal ammonia concentration and a higher volatile fatty acid (VFA) concentration when lambs were 20 to 50 days old. These data suggest that this yeast strain may stimulate the development of cellulolytic microflora and enhance microbial activity in the rumen of young ruminants. Such activity could be beneficial in preventing microbial imbalance and a reduction of rumen function efficiency in the case of nutritional transitions. Further studies with conventional animals will soon be performed in order to verify these findings.
\end{abstract}

rumen / probiotic / Saccharomyces cerevisiae / gnotobiotic lambs / plant cell wall degradation

Résumé - Implantation de bactéries cellulolytiques et développement des activités fermentaires dans le rumen d'agneaux gnotobiotiques recevant l'additif microbien Saccharomyces cerevisiae CNCM I-1077. Les effets d'une levure utilisée en alimentation du ruminant ont été étudiés sur l'implantation des bactéries cellulolytiques, la dégradation des parois végétales et le fonctionnement du rumen d'agneaux gnotobiotiques. Les bactéries cellulolytiques inoculées aux agneaux se sont implantées plus précocément en présence de Saccharomyces cerevisiae CNCM I-1077 (SC). De

\footnotetext{
* Correspondence and reprints
}

E-mail: fchauc@ clermont.inra.fr 
plus, leur population s'est maintenue à un niveau plus élevé, même lorsque les conditions physicochimiques du biotope étaient modifiées. Chez ces agneaux, les activités spécifiques des enzymes fibrolytiques étaient plus élevées, et la dégradation in sacco de la paille de blé augmentée. En présence de SC, une moindre concentration d'azote ammoniacal ruminal et une plus forte concentration d'acides gras volatils (AGV) étaient mesurées chez les animaux âgés de 20 à 50 jours. Ces données suggèrent que la souche de levure peut stimuler le développement de la microflore cellulolytique et favoriser l'activité microbienne dans le rumen de jeunes animaux. Les déséquilibres microbiens et la baisse d'efficacité du fonctionnement ruminal pourraient donc être prévenus par l'utilisation de ce probiotique lors de transitions alimentaires. Des études complémentaires effectuées chez des agneaux conventionnels permettront dans un avenir proche de confirmer ces résultats.

rumen / probiotique / Saccharomyces cerevisiae / agneaux gnotobiotiques / dégradation des parois végétales

\section{INTRODUCTION}

Yeasts such as strains of Saccharomyces cerevisiae are now widely used as additives in ruminant nutrition to improve animal performance and health.

Recent in vitro studies have shown that viable yeasts are able to stimulate the growth of rumen cellulolytic bacteria $[27,28]$ or fungi [5]. In vivo, the population of cellulolytic microflora of animals supplemented with yeasts increased in most cases [11]. However, very few papers address the effects of these microbial additives on plant cell wall breakdown in the rumen. Some yeasts have been shown to improve the rate of degradation of hay incubated in nylon bags $[3,33]$ and to increase NDF (neutral detergent fiber) disappearance from roughage diets $[26,30]$.

Strain CNCM I-1077 of Saccharomyces cerevisiae has been shown to stimulate the germination of zoospores and cellulose breakdown by Neocallimastix frontalis $\mathrm{MCH} 3$ [5] and also to have positive effects in vitro on bacteria playing key roles in the rumen $[6,7]$. However, its effect on fiberdegrading bacteria has not yet been investigated. The objective of our study was to investigate the role of this yeast strain of $S$. cerevisiae on microbial plant cell wall degradation in the rumen. To better understand the action of SC I-1077 on the different fiber-degrading communities, we used, as an animal model, gnotobiotically-reared lambs harbouring only bacteria (Fibrobacter succinogenes, Ruminococcus albus and Ruminococcus flavefaciens) as cellulosedegrading organisms. We determined the effect of SC I-1077 on the establishment of these bacteria in the rumen, on in sacco degradation of a lignocellulosic substrate, on the main polysaccharide depolymerase and glycoside hydrolase activities of particleassociated microorganisms, and on the development of the rumen digestive function.

\section{MATERIALS AND METHODS}

\subsection{Animals and diet (Fig. 1)}

Six naturally-born lambs were left with their dams for $24 \mathrm{~h}$ and placed in sterile isolators before cellulolytic microorganisms could become established, and were then reared gnotobiotically [17]. Until 40 days of age they were exclusively fed UHT-sterilized cow milk. From this age onwards they received a diet of dehydrated lucerne hay, in 7-mm pellets, sterilized by $\gamma$-irradiation (4Mrad, Lab. Caric, Orsay, France). Weaning was considered to begin at day 50 . When the animals were between 2.5 and 3 months old, they were fitted with a permanent cannula $(2.5 \mathrm{~cm}$ in diameter). They were 
Introduction into

a sterile isolator

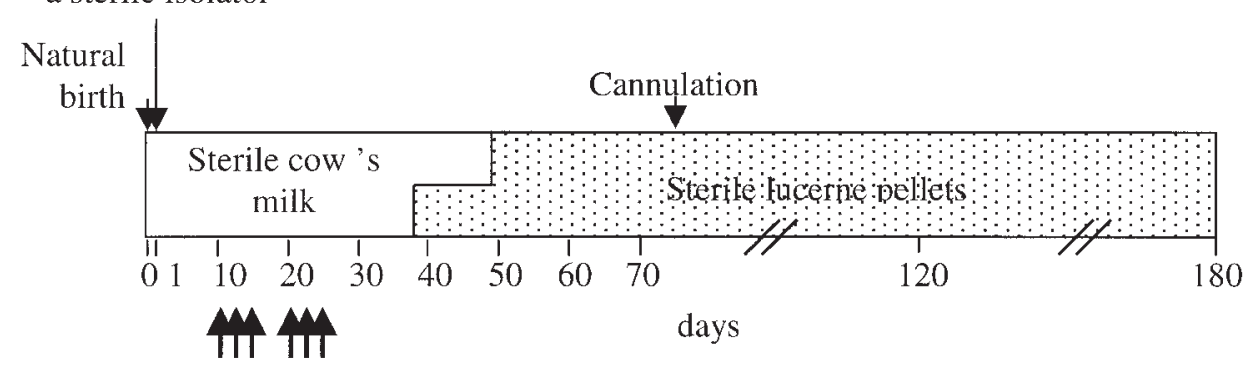

Enumeration of cellulolytic bacteria $-\mathrm{NH}_{3}$ and VFA analysis

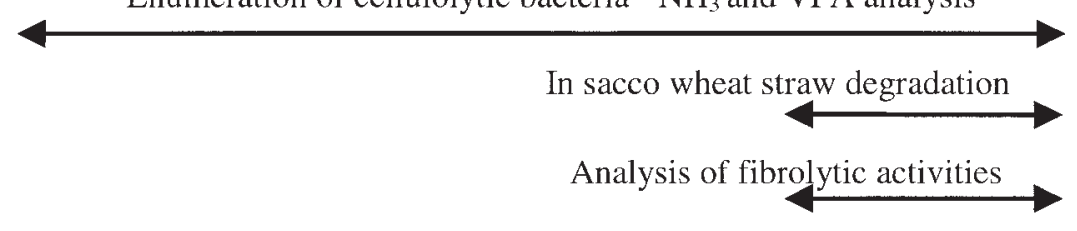

$\hat{\mathbf{T}}=$ Inoculation of a mixture of pure cultures of cellulolytic rumen bacteria

Figure 1. Experimental design.

reared in the isolators until the age of 6 months.

Three lambs given no additive were used as controls (group C); the other three ambs (group SC) daily received $100 \mathrm{mg}$ of Levucell ${ }^{\circledR} \mathrm{SC}$, containing $2 \times 10^{9} \mathrm{CFU}$ of Saccharomyces cerevisiae I-1077 (deposited in Collection Nationale des Cultures de Microorganismes, Institut Pasteur, Paris, France) during 175 days (total duration of the experiment). The product was resuspended in $9 \mathrm{~mL}$ of an anaerobic mineral solution [2] and given to the lambs before morning feeding with a stomach tube before the age of 3 months, and through the cannula after the age of 3 months.

\subsection{Inoculation of the lambs}

Microscopic observation of rumen fluid sampled from each lamb confirmed the absence of protozoa; cellulolytic bacteria, fungi and methanogenic archaea were not detected in the rumen fluid sampled on days 2, 4 and 8 in appropriate culture media (data not shown). Lambs were then inoculated on $\mathrm{d} 10-11-12$ and on $\mathrm{d} 21-22-23$ with $10 \mathrm{~mL}$ of 48-h-cellobiose-grown cultures of Fibrobacter succinogenes S85 (ATCC 19169) and 095 (Culture collection of the Lethbridge Research Center, Canada), Ruminococcus albus 7 (Culture collection of the University of Illinois at UrbanaChampaign, USA), and Ruminococcus flavefaciens 007 (Culture collection of the Rowett Research Institute, Aberdeen, Scotland) and FD1 (Culture collection of the University of Illinois at Urbana-Champaign, USA).

\subsection{Microbiological analysis}

Rumen samples were withdrawn before the morning meal and before distribution of SC I-1077 in group SC either by aspiration with a stomach tube or directly through the cannula, when the lambs were 1, 2 and 3 days old, and then at weekly intervals until week 20. 
Total viable anaerobic and cellulolytic bacteria were enumerated according to previously described methods [14].

The establishment of the three cellulolytic species $F$. succinogenes, $R$. albus and $R$. flavefaciens in the rumen of all the lambs, and their population dynamics in both groups were evaluated by hybridization of RNA extracts from rumen content samples, taken from lambs of different ages $(1,4,12$, 18 weeks after birth), with specific oligonucleotide probes targeting $16 \mathrm{~S}$ ribosomal RNA. Total RNA was extracted from $50 \mathrm{mg}$ of lyophilized rumen content, according to Chomczynski and Sacchi [9]. RNA extracts $(2$ and $1 \mu \mathrm{g})$ were blotted on nylon membranes (Biodyne B, Pall, Gelman Sciences) and hybridized with $\gamma-{ }^{32} \mathrm{P}-$ labeled oligonucleotide probes S-S-F.suc-0650a-A-20 [1], S-S-R.alb-0196-a-A-18 and S-S-R.fla-1269-a-A-20 [29] specific for $F$. succinogenes, $R$. albus and $R$. flavefaciens, respectively. Total RNA (100 and $50 \mathrm{ng}$ ) from pure cultures of $F$. succinogenes $\mathrm{S} 85$, $R$. albus $7, R$. flavefaciens FD1 and E. coli (universal standard, Boehringer Mannheim) were used as controls. Radioactivity associated with hybridization signals was detected with a STORM instrument (Molecular Dynamics).

Live yeasts were counted in the rumen samples on Petri dishes with malt agar containing antibiotics (streptomycin $0.025 \%$, ampicillin $0.04 \%$, chloramphenicol $0.03 \%$, tetracycline $0.012 \%$, neomycin $0.03 \%$ ) and lactic acid (10\%), after $48 \mathrm{~h}$ incubation at $30{ }^{\circ} \mathrm{C}[12]$.

\subsection{Measurement of ammonia and VFA}

During the 20-50 d period, the samples were obtained before the morning feeding. As soon as the lambs were old enough to ingest a solid diet in the form of a real meal, they were sampled before (T0) or $2 \mathrm{~h}$ after the meal (T2). After addition of $0.5 \%(\mathrm{v} / \mathrm{v})$ orthophosphoric acid, samples were stored at $-20{ }^{\circ} \mathrm{C}$ until analysis.
Ammonia and VFA concentrations were determined as previously described [14].

\subsection{Separation of microbial populations and enzyme preparation}

The enzymatic activities involved in plant cell wall degradation were measured in particle-associated rumen microbial populations separated from the rumen contents of the 4-month-old lambs, using the method described by Martin et al. [24]. One gram of chopped lucerne hay (particle size: approximately $1 \mathrm{~cm}$ long) was put into a nylon bag $(5 \times 10 \mathrm{~cm}$; porosity $50 \mu \mathrm{m})$ and introduced into the rumen through the cannula. Two bags were placed in each rumen. The operation was repeated four times for each lamb. After $24 \mathrm{~h}$ of incubation, bags were withdrawn and immediately placed in an anaerobic glove box (I2R, Cheltenham, Pennsylvania). The bag content was resuspended in anaerobic MES (2-(N-morpholino)ethane sulfonic acid) buffer $(25 \mathrm{mM}$, $\mathrm{pH} 6.5,4{ }^{\circ} \mathrm{C}$ ) containing DTT (dithiothreitol) $\left(0.2 \mathrm{mg} \cdot \mathrm{mL}^{-1}\right)$ and homogenized with a Stomacher 80 for $4 \mathrm{~min}$ at maximum speed to separate plant material. Cells of the adherent population were disrupted under $\mathrm{O}_{2}$-free $\mathrm{CO}_{2}$ by sonication (MSE Soniprep 150 disintegrator, MSE instruments, Crawley) during four periods of $30 \mathrm{~s}$ at maximum power with 30-s intervals at $4{ }^{\circ} \mathrm{C}$. Cell and plant material debris were eliminated by centrifugation $\left(5000 \mathrm{~g}, 15 \mathrm{~min}, 4^{\circ} \mathrm{C}\right)$; supernatants were stored at $-80{ }^{\circ} \mathrm{C}$ in screwcapped tubes gassed with $\mathrm{O}_{2}$-free $\mathrm{CO}_{2}$.

\subsection{Enzyme assay procedures}

Polyholoside- and glycoside-degrading enzymatic activities were determined as previously described [24]. Polysaccharidic substrates were microcrystalline cellulose (avicel PH101, Fluka), amorphous cellulose (carboxymethylcellulose CMC Sigma), and birchwood xylan (Sigma), prepared in MES DTT buffer $\left(2 \mathrm{mg} \cdot \mathrm{mL}^{-1}\right)$. Glycosidic 
substrates were paranitrophenyl-glycosides (Sigma): pNP- $\beta$-D-xylopyranoside, pNP$\beta$-D-cellobioside, $\mathrm{pNP}-\beta$-D-glucopyranoside, and pNP- $\beta$-D-galactopyranoside. The concentration of each substrate was $5 \mathrm{mM}$ in MES DTT.

\subsection{In sacco degradation of wheat straw}

Fiber degradation in the rumen of the 4-month-old gnotobiotically-reared lambs was determined by the nylon bag method [25]. Each bag (porosity $50 \mu \mathrm{m}$ ) contained $1 \mathrm{~g}$ of ground wheat straw. Bags were incubated in duplicate for 24 and $48 \mathrm{~h}$ in the rumen, and the incubations were repeated six times for each lamb, which represented 12 bags per lamb per incubation time. After incubation, the bags were removed from the rumen, washed, dried at $80^{\circ} \mathrm{C}$ and weighed. The amount of degraded wheat straw was then estimated by the percentage loss of dry matter.

\subsection{Statistical analysis}

In the tables, results are given as means \pm SD.; a Student t test [32] was used to compare the effects of SC I-1077 on wheat straw degradation, fibrolytic activities, ammonia and VFA. A non-parametric Mann-Whitney test was used to compare the means of fibrolytic bacterial numbers during the $12-42$ day period of age in both groups. Differences were considered to be significant at $P<0.10$.

\section{RESULTS}

\subsection{Establishment of the microbial communities}

All the total culturable anaerobic bacteria became rapidly established in the lamb rumens. The bacterial communities ranged between $4.6 \times 10^{7}$ and $2.3 \times 10^{8}$ cells $\cdot \mathrm{mL}^{-1}$ within $24 \mathrm{~h}$ after birth (Fig. 2A), and then increased during the first weeks to reach values close to those found in the rumens of conventional adult sheep. There was no detectable effect of SC I-1077 on total bacterial counts.

Cellulolytic bacteria were not detected in the rumen of all the lambs before inoculation of the three species $F$. succinogenes, $R$. albus and $R$. flavefaciens. Just after their introduction into the rumen, the cellulolytic organisms became rapidly established at high levels (Fig. 2B); hybridization signals (data not shown) indicated that $F$. succinogenes and $R$. albus were dominant in the rumen of all the lambs, while $R$. flavefaciens was at the detection limit (25 to $50 \mathrm{ng}$ $16 \mathrm{~S}$ rRNA in $50 \mathrm{mg}$ lyophilized rumen fluid). However, the cellulolytic population remained unstable, and tended to decrease until the second period of inoculation. Just after the second sequence of inoculation of cellulolytic bacteria, their number increased again. In group SC, the number of cellulolytic bacteria tended to increase more rapidly than in the control group. During the first month after their inoculation (from the 12th to 42 nd day after the birth of the animals), the cellulolytic bacterial number averaged $4.6 \times 10^{8}$ bacteria $\cdot \mathrm{mL}^{-1}$ in group SC, whereas it reached only $6.2 \times 10^{7}$ in group $C$. This difference was quite significant $(P=0.06)$.

After the cannula had been fitted (week 13), the number of cellulolytic bacteria in the rumen of all control lambs dropped. In contrast, the cellulolytic community remained stable in the rumen of lambs supplemented with yeasts.

Rearing lambs in a sterile controlled environment avoided contamination of the digestive tract by exogenous yeasts; SC I-1077 was the only yeast detected in group SC. During the first days of life of the lambs, yeast counts were close to those given daily to the animals. Yeasts were then progressively cleared from the rumen, although a proportion of cells survived in the rumen for $24 \mathrm{~h}$ (Fig. 2C). These results agreed with previous studies [12]. 
Group C : controls

Group SC : receiving strain SC I-1077
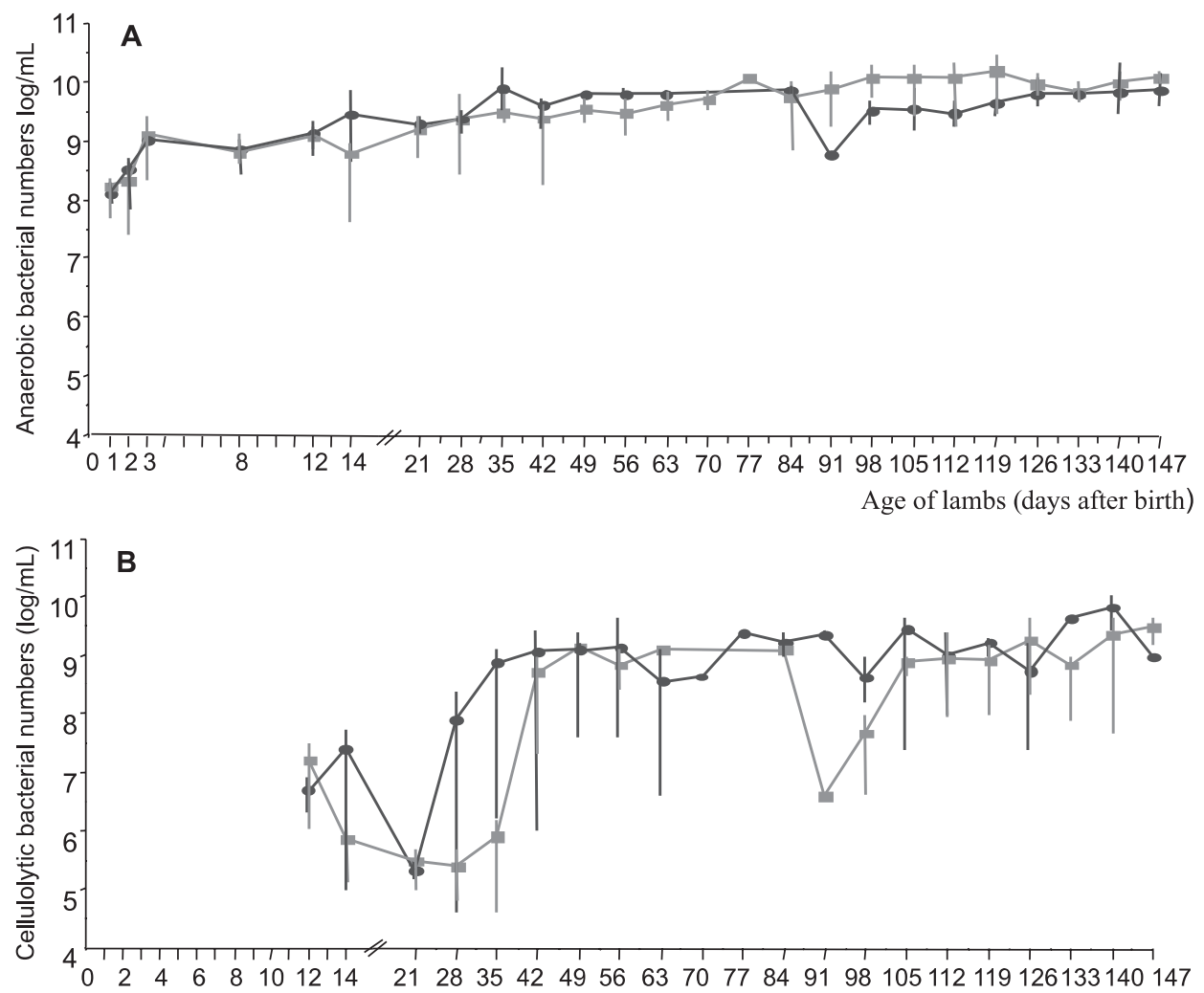

Age of lambs (days after birth)

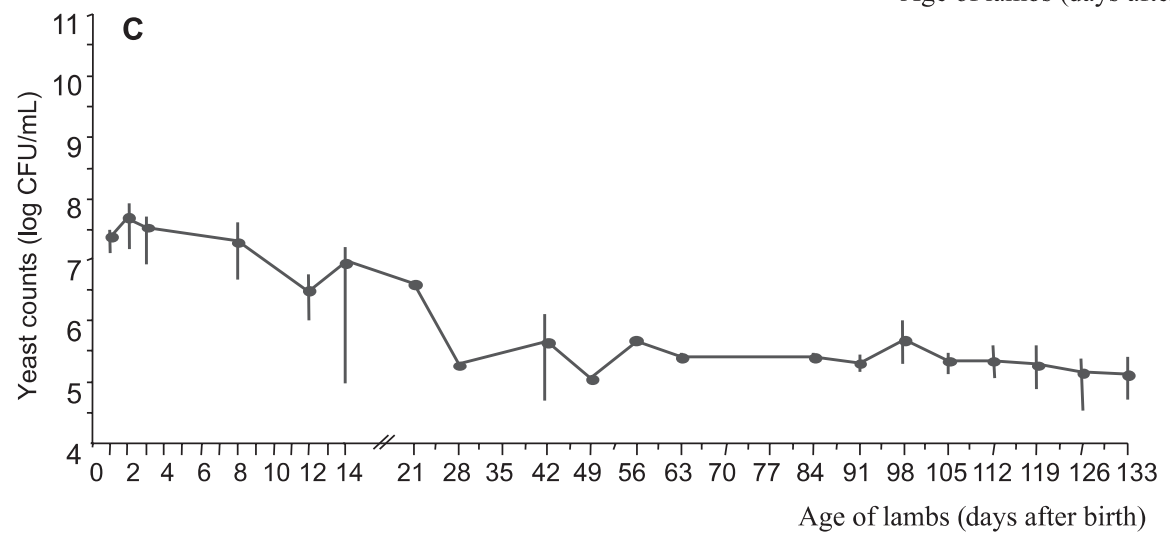

Figure 2. (A) Establishment of total anaerobic bacteria (log $m \mathrm{~L}^{-1}$ of rumen contents) in the rumen of lambs; (B) establishment of cellulolytic bacteria (log. $\mathrm{mL}^{-1}$ of rumen contents) in the rumen of lambs; (C) yeast counts $\left(\log\right.$ CFU $\left.\cdot \mathrm{mL}^{-1}\right)$ in the rumen of lambs SC. Results are expressed as mean $\log \cdot \mathrm{mL}^{-1}$ and bars show the range between the lowest and the highest log values. 


\subsection{VFA and ammonia analysis}

The ruminal volatile fatty acid concentration ranged widely in the lambs (Tab. IA). It tended to increase when the lambs began to ingest solid feed, and after weaning reached values close to those measured in adult ruminants (between 70 and $100 \mathrm{mM}$ ). VFA concentration was higher in the rumen of lambs from group SC during the 20-50 d period $(P=0.08)$. During the $50-140 \mathrm{~d}$ period, ruminal concentration of VFA increased after feeding in both groups of lambs; there was no effect of SC I-1077 during this period. Moreover, no effect of SC was observed on the centesimal composition of the major VFA mixture (Tab. IB), nor on the composition of branched-chain VFA whose concentrations were less than 1 $\mathrm{mM}$ (data not shown).

Table I. (A) Total VFA concentrations $\left(\mathrm{mmol} \cdot \mathrm{L}^{-1}\right)$, (B) Percentages of acetate, propionate and butyrate in rumen contents of gnotobiotically-reared lambs from group C (controls) and group SC (receiving Levucell ${ }^{\circledR}$ SC, SC I-1077), before weaning (age 20-50 days) and after weaning (age $50-140$ days). Results are expressed as mean \pm SD of more than 6 determinations. (C) Ammonia concentration $\left(\mathrm{mg} \cdot \mathrm{L}^{-1}\right)$ in rumen contents of both groups before weaning $(20-50 \mathrm{~d})$, after weaning, before cannula fitting (50-78 d), and after cannula fitting (84-140 d).

\begin{tabular}{ccc}
\multicolumn{4}{c}{ Age of lambs (d) } \\
\hline $20-50 \mathrm{~d}$ \\
\cline { 2 - 3 } T0 & \multicolumn{3}{c}{$50-140 \mathrm{~d}$} \\
T0 & T2
\end{tabular}

\begin{tabular}{|c|c|c|c|c|}
\hline \multicolumn{5}{|l|}{ (A) } \\
\hline \multicolumn{5}{|c|}{ Total VFA $\left(\mathrm{mmol} \cdot \mathrm{L}^{-1}\right)$ : } \\
\hline Group C & \multicolumn{2}{|c|}{$18.0 \pm 5.0$} & $79.6 \pm 14.7$ & $97.0 \pm 21.4$ \\
\hline Group SC & \multicolumn{2}{|c|}{$31.1 \pm 8.4^{*}$} & $72.2 \pm 24.3$ & $98.4 \pm 14.8$ \\
\hline \multicolumn{5}{|l|}{ (B) } \\
\hline \multicolumn{5}{|l|}{ Acetate $(\%)$ : } \\
\hline Group C & \multicolumn{2}{|c|}{$76.3 \pm 10.1$} & $67.7 \pm 4.5$ & $70.1 \pm 3.7$ \\
\hline Group SC & \multicolumn{2}{|c|}{$81.3 \pm 3.3$} & $69.0 \pm 3.8$ & $67.0 \pm 2.8$ \\
\hline \multicolumn{5}{|c|}{ Propionate (\%): } \\
\hline Group C & \multicolumn{2}{|c|}{$16.3 \pm 4.2$} & $21.8 \pm 7.0$ & $21.2 \pm 6.3$ \\
\hline Group SC & \multicolumn{2}{|c|}{$14.3 \pm 2.6$} & $21.5 \pm 5.2$ & $23.3 \pm 1.8$ \\
\hline \multicolumn{5}{|l|}{ Butyrate (\%): } \\
\hline Group C & \multicolumn{2}{|c|}{$4.3 \pm 6.0$} & $6.9 \pm 2.4$ & $6.6 \pm 2.9$ \\
\hline \multirow[t]{4}{*}{ Group SC } & \multicolumn{2}{|c|}{$3.5 \pm 2.4$} & $7.3 \pm 2.6$ & $7.7 \pm 0.8$ \\
\hline & \multicolumn{4}{|c|}{ Age of lambs (d) } \\
\hline & \multirow{2}{*}{$\begin{array}{c}20-50 \mathrm{~d} \\
\mathrm{~T} 0\end{array}$} & \multirow{2}{*}{$\begin{array}{c}50-78 \mathrm{~d} \\
\text { T0 }\end{array}$} & \multicolumn{2}{|c|}{$84-140 \mathrm{~d}$} \\
\hline & & & T0 & $\mathrm{T} 2$ \\
\hline \multicolumn{5}{|c|}{ (C) } \\
\hline \multicolumn{5}{|c|}{$\mathrm{N}-\mathrm{NH}_{3}\left(\mathrm{mg} \cdot \mathrm{L}^{-1}\right):$} \\
\hline Group C & $121.0 \pm 28.3$ & $124.7 \pm 29.8$ & $208.8 \pm 107.3$ & $198.5 \pm 81.2$ \\
\hline Group SC & $100.3 \pm 33.3$ & $124.5 \pm 30.4$ & $92.8 \pm 84.4$ & $155.3 \pm 73.7$ \\
\hline
\end{tabular}

SC: Effect is significant, $* P<0.10$.

T0: Samples were obtained before the morning feed; T2: samples were obtained $2 \mathrm{~h}$ after feeding. 
Table II. Depolymerase and glycoside hydrolase specific activities (nmol $\cdot \mathrm{min}^{-1} \cdot \mathrm{mg}^{-1}$ protein) of particle-associated bacteria in the rumen of lambs from group C and SC. Results are expressed as mean $\pm \mathrm{SD}$ of more than 8 determinations.

\begin{tabular}{lcc}
\hline & Group C & Group SC \\
\hline CMCase & $1018.9 \pm 736.83$ & $852.9 \pm 300.8$ \\
Avicelase & $108.9 \pm 166.3$ & $122.0 \pm 111.0$ \\
Xylanase & $15358.0 \pm 5126.3$ & $22481.0 \pm 6811.5$ \\
& & \\
$\beta$-galactosidase & $3132.1 \pm 1264.0$ & $6885.5 \pm 1795.3^{* *}$ \\
$\beta$-glucosidase & $2003.3 \pm 439.6$ & $4123.3 \pm 1225.3^{* *}$ \\
$\beta$-xylosidase & $1998.1 \pm 762.8$ & $2614.7 \pm 599.4$ \\
$\beta$-cellobiohydrolase & $1136.8 \pm 727.3$ & $1409.3 \pm 420.5$ \\
\hline
\end{tabular}

SC: effect is significant, $* * P<0.05$.

Wide variations in concentrations of ammonia appeared between lambs. During the 20-50 d period, ammonia concentration tended to be slightly lower in group SC than in group C (Tab. IC). Ammonia concentrations increased after week 11 , reaching approximately $200 \mathrm{mg} \cdot \mathrm{L}^{-1}$ in group C. In group $\mathrm{SC}$, ammonia concentration was lower $\left(92.8 \mathrm{mg} \cdot \mathrm{L}^{-1}\right.$ before feeding and $155.3 \mathrm{mg} \cdot \mathrm{L}^{-1}$ two $\mathrm{h}$ afterwards), but given the low numbers of animals this difference was not significant.

\subsection{Fibrolytic activities}

Of all the depolymerase activities, hemicellulase (xylanase) exhibited the highest activity, whereas the activities of cellulases (CMCase and avicelase) were lower (Tab. II). Variations between animals were very marked. Although there was no variation in CMCase-, avicelase-, and $\beta$-cellobiosidase-specific activities between groups $\mathrm{C}$ and SC, significant differences in $\beta$-glucosidase and $\beta$-galactosidase activities were observed in the presence of SC I-1077, these activities being almost doubled, and xylanase and xylosidase activities tended to be greater.

\subsection{In sacco wheat straw degradation}

Dry matter (DM) loss data from one lamb of group SC had to be discarded because of technical problems during the collection of nylon bags.

Wheat straw DM degradation in the bags tended to be higher in lambs receiving SC I-1077 after $24 \mathrm{~h}(+5.0 \%)$ and was greater $(P$ value was slightly above 0.10$)$ after $48 \mathrm{~h}(+9.8 \%)$ of incubation in the rumen. Percentages of DM disappearance were $23.01 \pm 7.53$ vs. $29.16 \pm 6.72$ after $24 \mathrm{~h}$ and $24.17 \pm 4.39$ vs. $32.03 \pm 4.86$ after $48 \mathrm{~h}$ in the C and SC groups, respectively.

\section{DISCUSSION}

Leaving the lambs in a conventional environment for $24 \mathrm{~h}$ enabled a microflora of some complexity to colonize the rumen, which is required for the successful establishment of cellulolytic bacteria [14, 16]. The three cellulolytic species $(F$. succinogenes, $R$. albus, $R$. flavefaciens) became established in all the lambs, as demonstrated with oligonucleotide probes.

Owing to the difficulty of rearing animals for a long time in gnotobiotic conditions, our experiment was carried out with a 
small number of lambs, which did not enable us to show significant effects of SC on several parameters taken into account in this study. However, this study suggests that Saccharomyces cerevisiae I-1077, given daily to young gnotobiotically-reared lambs, may to a varying extent influence the microbial colonization of the rumen. No significant variation of the total culturable anaerobic bacteria in the presence of SC I-1077 was observed, but the establishment of cellulolytic bacteria at a high level of population seemed to be accelerated. Total viable counts have generally been reported to increase after the addition of yeasts [11], but these results were obtained with adult ruminants, which harboured a more complex microflora than that present in the rumen of gnotobiotic lambs used in this study. Stimulatory effects on cellulolytic bacterial numbers have been noted in vitro and in sheep by Newbold et al. [27], and the growth of $F$. succinogenes and $R$. albus has been reported to be stimulated in vitro by a strain of Saccharomyces cerevisiae [10]. To find out more about the effect of SC I-1077 on each cellulolytic species, dot blot hybridization with specific probes was performed. However, it was impossible to evaluate the possible effect of SC because the $R$. flavefaciens rRNA population was at the detection limit whatever the age of the lambs, and because the variations between lambs in rRNA detected for each cellulolytic species were too great.

It is assumed that just after birth, when the rumen is not functional yet, the microflora is involved in the development of rumen physiology and digestive functions [18]. The higher level of cellulolytic bacterial community in the rumen of lambs receiving the yeast additive indicates that the yeasts may enhance the development of ruminal functions. This hypothesis is also supported by the slightly higher concentration of fermentation end products (VFA) during the 20-50 d period in SC lambs.

Stimulation of the growth of cellulolytic bacteria by SC could be due to nutrients provided by the yeasts, because yeasts have been shown to stimulate zoospore germination and cellulolytic activity of the fungal strain Neocallimastix frontalis $\mathrm{MCH}$, by supplying thiamin to the fungus [5]. The ability of live SC to consume oxygen entering the rumen could also be involved. This hypothesis is supported by the fact that after cannula fitting, the number of cellulolytic bacteria decreased into the rumen of the control lambs. This decline was probably due to the entry of oxygen in the rumen during surgery, which exerted an inhibitory effect on cellulolytic bacteria in group $\mathrm{C}$. Cellulolytic species are known to be extremely oxygen-sensitive and indeed oxygen acts as a toxic substance [21]. The fact that the cellulolytic population remained stable in group SC is consistent with the role of $\mathrm{SC}$ on oxygen scavenging recently demonstrated in vitro [4] and in lambs [8]. In addition, using Rusitec, Newbold et al. [28] have shown that counts of rumen bacteria increased when yeasts were likely to have a respiratory activity, whereas they did not vary in the presence of non-respiratory mutants of the same yeast strains. By consuming oxygen, SC I-1077 maintained the physico-chemical conditions of the biotope which are compatible with the requirements of the cellulolytic bacteria. This oxygenscavenging capacity of SC I-1077 would be of particular interest during weaning, when young ruminants begin to ingest solid feed particles and water, but also during rumination and salivation. With feed intake, saliva production and rumination, up to 38 litres of oxygen enter the rumen daily [28]. Oxygen adsorbed on plant material entering the rumen is considered to limit bacterial attachment and consequently cellulolytic activities [31].

In the presence of strain SC I-1077, several enzymatic activities of solid digestaadherent microflora increased and the degradation of wheat straw in sacco was also higher. In adult sheep, comparable results were obtained with another strain of SC, which stimulated the xylanase and CMCase 
activities of particle-associated microorganisms [23]. Digesta-adherent microorganisms represent more than $75 \%$ of the total microflora in the rumen of conventional animals, and the three fiber-degrading bacterial species used in this study are known to be the major species in the rumen and are very active in plant cell wall breakdown because they exhibit numerous cellulases (e.g. glucanases, glucosidases) and hemicellulases (e.g. xylanases, xylosidases, fucosidases) $[19,20]$. In our study, the stimulation of these 3 species by SC I-1077 may be responsible, in part, for the increase in hemicellulolytic activities. However, other bacterial species, that colonize the rumen during the first hours after birth, and that may be present in the rumen of gnotobiotic animals used in this study, are also known to produce hydrolases involved in plant cell wall degradation. For example, some ruminal species of the genus Prevotella synthetise exo- and endoxylanases; Butyrivibrio fibrisolvens is also able to degrade xylans very efficiently [20]. These bacterial species have been shown to be among the first colonizers of the rumen of newborn lambs [15]. Therefore, their stimulation by SC I-1077 cannot be excluded.

In the control group, ammonia concentration tended to be higher than in the SC group after cannulation, indicating that surgery may induce perturbation of rumen functions. During that period, as we previously noted, a decline in cellulolytic bacterial numbers was also recorded. The accumulation of ammonia in the control group could be related in part to the decrease in cellulolytic bacterial counts, as cellulolytic bacteria are known to utilize ammonia as a nitrogen source preferentially to peptides or amino acids [22]. On the contrary, in lambs receiving Levucell ${ }^{\circledR} \mathrm{SC}$, cellulolytic bacterial counts remained unchanged and, in parallel, ammonia concentration was lower, suggesting that strain SC I-1077 could either stimulate ammonia uptake by the cellulolytic bacteria, which would allow better growth of these species in the rumen, or stimulate the growth of cellulolytic bacteria, which could use more ammonia to synthetise cellular nitrogenous components. Bacteria other than cellulolytic were probably also stimulated. Some yeast additives have been shown to reduce ammonia concentration in vitro [10] and in vivo [13, 33], and, in parallel, a greater microbial synthesis was observed.

\section{CONCLUSION}

These data suggest that $S$. cerevisiae CNCM I-1077, used as a microbial additive in the rumen of gnotobiotically-reared lambs, may influence the microbial balance and modulate the intensity of ruminal fermentation. The mechanism by which this occurs is not yet clearly understood; yeasts may favor the establishment of fibrolytic bacteria, probably by providing them with better physico-chemical and nutritional conditions. As the microflora became established a little earlier, the development of microbial activities tended to accelerate. Supplying young ruminants with strain SC I-1077 could thus be of value in stabilizing the rumen microbial ecosystem when animals switch over from a milky diet to solid feed.

\section{ACKNOWLEDGEMENTS}

We would like to thank M. Theveniot, L. Millet, G. Andant and R. Roux for technical assistance, and M. Chavarot, G. Vert, and C. Demartrin for their help in rearing the animals.

\section{REFERENCES}

[1] Amann R.I., Krumholtz L., Stahl D.A., Fluorescent oligonucleotide probing of whole cells for determinating, phylogenetic, and environmental studies in microbiology, J. Bacteriol. 172 (1990) 762-770.

[2] Bryant M.P., Burkey L.A., Cultural methods and some characteristics of some of the more numerous groups of bacteria in the bovine rumen, J. Dairy Sci. 36 (1953) 218-224. 
[3] Chademana I., Offer N.W., The effect of dietary inclusion of yeast culture on digestion in the sheep, Anim. Prod. 50 (1990) 483-489.

[4] Chaucheyras F., Ph.D. thesis, Université Blaise Pascal, Clermont-Ferrand II, 1995, n 129.

[5] Chaucheyras F., Fonty G., Bertin G., Gouet P., Effects of live Saccharomyces cerevisiae cells on zoospore germination, growth and cellulolytic activity of the rumen anaerobic fungus Neocallimastix frontalis $\mathrm{MCH} 3$, Curr. Microbiol. 31 (1995) 201-205

[6] Chaucheyras F., Fonty G., Bertin G., Gouet P., In vitro $\mathrm{H} 2$ utilization by a ruminal acetogen bacterium cultivated alone or in association with an archaea methanogen is stimulated by a probiotic strain of Saccharomyces cerevisiae, Appl. Env. Microbiol. 61 (1995) 3466-3467.

[7] Chaucheyras F., Fonty G., Bertin G., Salmon J.M., Gouet P., Effect of a strain of Saccharomyces cerevisiae (Levucell $\left.{ }^{\circledR} \mathrm{SC}\right)$, a microbial additive for ruminants, on lactate metabolism in vitro, Can. J. Microbiol. 42 (1996) 927-933.

[8] Chaucheyras-Durand F., Fonty G., Bertin G., Effects of a strain of Saccharomyces cerevisiae CNCM I-1077, used as a feed additive for ruminants, on the rumen microflora, in: Proccedings of the 8th International Symposium on Microbial Ecology, Halifax, 1998, p. 122.

[9] Chomczynski P., Sacchi N., Single-step method of RNA isolation by acid-guanidium thiocyanate-phenol-chloroform extraction, Anal. Biochem. 162 (1987) 156-159.

[10] Dawson K.A., Current and future role of yeast culture in animal production: a review of research over the last six years. Supplement of the proceedings of Alltech's 8th annual symposium, Alltech Technical Publications, Lexington, 1992, pp. 1-23.

[11] Durand-Chaucheyras F., Fonty G., Bertin G., L'utilisation de levures vivantes, additifs microbiens chez le ruminant: effets sur la microflore et les fermentations ruminales, effets zootechniques. Bull. G.T.V. 5B-576 (1997) 35-52.

[12] Durand-Chaucheyras F., Fonty G., Bertin G., Théveniot M., Gouet P., Fate of Levucell ${ }^{\circledR}$ SC I-1077 yeast additive during digestive transit in lambs, Reprod. Nutr. Dev. 38 (1998) 275-280.

[13] Erasmus L.J., Botha P.M., Kistner A., Effect of yeast supplement on production, rumen fermentation, and duodenal nitrogen flow in dairy cows, J. Dairy Sci. 75 (1992) 3056-3065.

[14] Fonty G., Gouet P., Jouany J.P., Sénaud J., Ecological factors determining the establishment of cellulolytic bacteria and protozoa in the rumen of meroxenic lambs, J. Gen. Microbiol. 129 (1983) 213-223.

[15] Fonty G., Gouet P., Jouany J.P., Sénaud J., Establishment of the microflora and anaerobic fungi in the rumen of lambs, J. Gen. Microbiol. 133 (1987) 1835-1843.
[16] Fonty G., Gouet P., Jouany J.P., Establishment of Bacteroides succinogenes and measurement of the main digestive parameters in the rumen of gnotoxenic lambs, Can. J. Microbiol. 34 (1988) 39-46.

[17] Fonty G., Gouet P., Nebout J.M., Development of the cellulolytic microflora in the rumen of lambs transferred into sterile isolators a few days after birth, Can. J. Microbiol. 35 (1989) 416-422.

[18] Fonty G., Jouany J.P., Chavarot M., Bonnemoy F., Gouet P., Development of the rumen digestive functions in lambs placed in a sterile isolator a few days after birth, Reprod. Nutr. Dev. 31 (1991) 521-528.

[19] Fonty G., Jouany J.P., Forano E., Gouet P, L'écosystème microbien du réticulo-rumen, in: Jarrige R., Ruckebusch Y., Demarquilly C., Farce M.H., Journet M. (Eds.), Nutrition des ruminants domestiques, INRA editions, Paris, 1995, pp. 299-347.

[20] Forano E., Les enzymes microbiennes du rumen impliquées dans la dégradation des parois végétales, C.R. Agric. Fr. 84 (1998) 149-158.

[21] Hungate R.E., The rumen and its microbes, Academic Press, New York and London, 1966.

[22] Jouany J.P., Broudiscou L., Prins R.A., Komisarczuk-Bony S., Métabolisme et nutrition de la population microbienne du rumen, in: Jarrige R., Ruckebusch Y., Demarquilly C., Farce M.H., Journet M. (Eds.), Nutrition des ruminants domestiques, INRA éditions, Paris, 1995, pp. 349-381.

[23] Jouany J.P., Mathieu F., Sénaud J., Bohatier J., Bertin G., Mercier M., The effect of Saccharomyces cerevisiae and Aspergillus oryzae on the digestion of the cell wall fraction of a mixed diet in defaunated and refaunated sheep rumen, Reprod. Nutr. Dev. 38 (1998) 401-416.

[24] Martin C., Michalet-Doreau B., Fonty G., Williams A.G., Postprandial variations in the activity of polysaccharide-degrading enzymes of fluid and particle-associated ruminal microbial populations, Curr. Microbiol. 27 (1993) 223-228.

[25] Michalet-Doreau B., Use of in sacco method to predict the feeding values of forages, Proc. 16th Int Grass Congress, 4-11 October, Nice, INRA France, 3 (1990) 1850-1852.

[26] Mpofu I.D.T., Ndlovu L.R., The potential of yeast and natural fungi for enhancing fibre digestibility of forages and roughages, Anim. Feed Sci. Technol. 48 (1994) 39-47.

[27] Newbold C.J., Wallace R.J., Chen X.B., McIntosh F.M., Different strains of Saccharomyces cerevisiae differ in their effects on ruminal bacterial numbers in vitro and in sheep, J. Anim. Sci. 73 (1995) 1811-1818.

[28] Newbold C.J., Wallace R.J., McIntosh F.M. Mode of action of the yeast Saccharomyces cerevisiae as a feed additive for ruminants, $\mathrm{Br}$. J. Nutr. 76 (1996) 249-261. 
[29] Odenyo A.A., Mackie R.I., Stahl D.A., White B.A., The use of 16SrRNA-targeted oligonucleotide probes to study competition between ruminal fibrolytic bacteria: Pure culture studies with cellulose and alkaline peroxide-treated wheat straw, Appl. Environ. Microbiol. 60 (1994) 3697-3703.

[30] Plata F.P., Mendoza G.D.M., Barcena-Gama J.R., Gonzalez S.M., Effect of a yeast culture (Saccharomyces cerevisiae) on neutral detergent fiber digestion in steers fed oat straw based diets, Anim. Feed Sci. Technol. 49 (1994) 203-210.

[31] Roger V., Fonty G., Komisarczuk-Bony S., Gouet P., Effects of physicochemical factors on the adhesion to cellulose avicel of the ruminal bacteria Ruminococcus flavefaciens and Fibrobacter succinogenes subsp. succinogenes, Appl. Environ. Microbiol. 53 (1990) 3081-3086.

[32] Snedechor G.W., Cochran W.G., Statistica methods, Iowa State University Press, Ames, USA, 1994.

[33] Williams P.E.V., Tait C.A.G., Innes G.M., Newbold C.J., Effects of the inclusion of yeast culture (Saccharomyces cerevisiae plus growth medium) in the diet of dairy cows on milk yield and forage degradation and fermentation patterns in the rumen of steers, J. Anim. Sci. 69 (1991) 3016-3026 